\title{
Fifth European Congress of Cardiology
}

The Fifth European Congress took place in Athens from September 8 to 14, 1968. The inaugural ceremony was held in the historic and lovely Odeon of Herodes Atticus, lying beneath the floodlit Acropolis, a most awesome and impressive venue. Professor Michaelides, Dr. Samaras, and the Organizing Committee deserve great praise for the thoughtful organization and smooth running of the Congress. At the inaugural ceremony Sir Kempson Maddox quoted Singer, "Scientific medicine began with the Greeks", and enlarged on the historical background of Greek medicine.

The Scientific sessions were held in the newly completed Panteios School of Political Sciences that provided excellent facilities in one large and three smaller theatres. The former was used for morning symposia, round-table discussions and lectures without distraction from simultaneous events elsewhere. Individual papers were confined to afternoon sessions, and subjects were arranged to follow the morning's topic, where possible. Subjects discussed at symposia included results of valve replacement, somewhat incomplete in the absence of any British contributions, and medical and surgical treatment of angina which revealed an interesting national difference with regard to the use of MAO inhibitors, recommended by the French but not by the Germans. Electrocardiography, non-traumatic diagnostic methods, pacemaking, hypertension, cellular function, aetiology of congenital heart disease and cardiomyopathies, were the remaining topics for the morning symposia and round-table conferences. A criticism of some of these was the lack of time to deal with questions from the floor. Again, the objectives of such symposia seemed to differ: some presented a comprehensive review of established principles, while others were confined to a series of personal experiences by the contributors; only a few produced controversy over recent results. Two lectures were given by Lenègre (Paris) and by Condorelli (Rome).

The afternoon sessions lasted from 3 to 7 p.m. and included six British contributions on the results of cardiac surgery. Apart from continuing the morning topics, other subjects dealt with in afternoon papers included various aspects of coronary disease, surgery of congenital heart disease, beta-blocking drugs, and aspects of heart failure.

The social programme followed the ever-generous traditions of Greek hospitality at receptions, visits to Euripedes' "Alcestis", to "Son et Lumière" at the Acropolis, folk dancing displays and a cruise to the island of Aegina. Visits to museums, monasteries and markets were enjoyed by the ladies (and by some delegates). Many members of the Congress combined the meeting with a holiday either preceding or following, and so were able to make excursions to some of the many beautiful Greek islands or to historic sites, such as Delphi, Epidaurus, Corinth, Mycaenae, and Olympia.

In addition to expressing our gratitude to the official organizers of the Congress we take this opportunity of expressing our warm thanks to many hosts for much private and delightful hospitality that we all received in Athens.

Edwin Besterman 